\title{
nature
}

\section{Opportunity ahead for Europe}

\section{The European Commission has enormously improved its administration of the Community's research programme. But there is a long way to go.}

THE European Community's research programme continues to become more tangible and hard-headed. Several months have already passed since, in an almost once and for all break with precedent, the European Commission provided a meeting of research ministers from member states with an agenda that was well prepared (see Nature 297, 613 and 619; 1982). The preparations for next month's meeting in the same series are even better - there is less paper but more time in which to read it (see page 188). The chances are therefore good that the participants in next month's meeting will retain a clear sense of what they have accomplished, and will thus be doubly well prepared to take part in the next meeting. The way things are going, it is no longer outrageously overhopeful to suppose that meetings of what is called in Brussels the Science Council will be memorable for the constructiveness of their discussion and the clarity of their decisions. Yet it is too soon to know when the European Community will have a policy for research and development that is at once appropriate and effective.

The difficulty is constitutional, and not of the Commission's making. The Commission is not a government but, rather, an organization whose existence is assured by the Treaty of Rome but whose role is only partly defined by what the treaty says. The Commission is required to stamp out restraints on competition between member states, if necessary by taking member governments to the European Court or by promulgating directives which have the force of law. It also has explicit treaty obligations for the administration of European agricultural policy. But in other fields, such power as the Commission enjoys depends on the willingness of member governments to relinquish responsibility to Brussels. It is not in the circumstances surprising that the hard core of what the Commission is pleased to call its "research, development and demonstration"' programme should consist of projects such as in thermonuclear fusion; none of the member governments would think it worthwhile supporting a viable programme of research of its own, but most of them fall in with the proposition that something substantial should be done collectively. The result is that the Commission is now proposing to spend 480 million European Units of Account (the paper currency unit now almost exactly equal to one US dollar once again) on fusion over the next three years (most of it on the Joint European Torus, much of the rest on the Next European Torus). This also explains the Commission's substantial research programme on safety aspects of fission reactors. Member governments find the arrangement convenient; otherwise, they would not foot the bill.

But need the planning of the Community's research programme always have this makeshift character? While the Treaty of Rome remains the Community's rule-book, and for as long as the day to day conduct of the Community's affairs is determined by short-term calculations of narrow self-interest, there is probably no alternative. If the Commission is ever to win member governments' consent to a less grudging central research programme, the following conditions will have to be satisfied.

- Central expenditure should threaten nobody but be a convenience to member governments. This condition is satisfied by the collaborative research programme on thermonuclear fusion but was not satisfied by the Community's ambitious plans more than a decade ago to launch a collaborative research programme on computer design (which is why nothing ever came of it). The problems with which the Community must learn to live are entirely familiar to those who manage research programmes whose cost is met by contributions from members which are ordinarily competitors of each other. So substantial opportunities for spending money centrally will be found in large long-term projects (fusion), public service projects (nuclear waste disposal), basic research (in most fields), and those which are best dealt with collaboratively (such as the effects of acid rain).

- Centrally administered research must not create a huge establishment of its own. The Euratom research organization failed primarily because its plans for reactor-types were too fanciful, but its one-time existence is still marked by the survival of the Community's Joint Research Centre at Ispra. Making fuller use of this and establishments that cannot simply be closed down remains a continuing practical preoccupation for Brussels even though it should in due course wither away.

- The Community's selection of projects to support should carry the same kind of conviction as do the programmes of the more reputable grant-making agencies. One obvious snag is that conventional techniques of peer review are not easily applicable across the whole of such a wide field, and in circumstances in which over-pious statements of general objectives are likely for a long time to be the rule. Qualitatively, however, the Commission's practice in the past few years seems to have been heading in the right direction.

Quantitatively, there is a long way to go. The agenda paper for next month's Science Council points out that the total spending on research and development within member states amounts to a fifth of the world's total, and that European member governments collectively spend on research and development 70 per cent of what the United States spends on these activities and more than three times what the government of Japan affords - a slightly confusing comparison because the ratio of private to public research in Japan is more like 70:30 than 50:50 as in Europe and the United States. The implication is that Europe collectively could give its principal industrial competitors a run for their money on research and development. Mercifully, next month's agenda paper stops short of implying that all this would happen if only governments would hand over to Brussels a larger proportion of what they spend on research and development. Realism seems to have supervened.

So in what directions should the new research team at Brussels be hoping to expand? The most obvious opportunity is in basic research. The Commission is exceptionally well placed, being qualified to spend funds on multinational projects when member states might be prevented from doing so by domestic legislation. The European Science Foundation has shown that there are plenty of opportunities for using modest sums of money sensibly, especially on assisting collaboration between groups of people or between institutions. The Commission should be aiming to take a leaf out of the foundation's book - the best immediate opportunity for spending money in ways that will quickly improve the quality of European research. Further ahead, however, the objective must be to monitor the pattern of European trade in high technology to find ways in which the changing division of labour between the members of the European Community makes sense of centrally sponsored research. This will be a slow job, but it is both the best and the only way forward. 